Article

\title{
Effect of Natural Forest Fires on Regional Weather Conditions in Siberia
}

\author{
Alexander Kirsanov ${ }^{1,2}$, Inna Rozinkina ${ }^{1}$, Gdaliy Rivin ${ }^{1,3}$, Denis Zakharchenko ${ }^{1,3}$ and \\ Alexander Olchev ${ }^{3, * \text { D }}$ \\ 1 Hydrometeorological Research Center of the Russian Federation, Bolshoi Predtechenskiy Per. 11-13, \\ 123242 Moscow, Russia; heu3becteh@mail.ru (A.K.); inna.rozinkina@mail.ru (I.R.); \\ gdaly.rivin@mail.ru (G.R.); dozentmi7@mail.ru (D.Z.) \\ 2 Obukhov Institute of Atmospheric Physics, Russian Academy of Sciences, Pyzhyovskiy Per.3, \\ 119017 Moscow, Russia \\ 3 Department of Meteorology and Climatology, Faculty of Geography, Lomonosov Moscow State University, \\ GSP-1, Leninskie Gory, 119991 Moscow, Russia \\ * Correspondence: aoltche@gmail.com
}

Received: 12 September 2020; Accepted: 19 October 2020; Published: 21 October 2020

\begin{abstract}
Effects of forest fires on regional weather conditions were analyzed for Central and Eastern Siberia after warm and dry weather conditions in summer 2019 using COSMO-Ru (COnsortium for Small-scale MOdeling; Ru-Russia) and COSMO-RuART (ART-Aerosols and Reactive Trace gases) model systems. Four series of numerical experiments were conducted (one control experiment and three forest fire experiments assuming total vegetation destruction within the burned areas) to evaluate possible effects of forest fires on surface albedo and vegetation properties as well as their influence on air chemistry and aerosol concentration in the atmosphere. The modeling results showed significant influence of forest fires on regional weather conditions that occurred over large areas situated even away from burnt regions. Decreased surface albedo and reduced latent heat fluxes due to fire-induced destruction of forest cover lead to higher near-surface air temperature and lower air humidity in both burned and surrounding unburned forest areas. On the other hand, reduced incoming solar radiation due to smoke from forest fire plumes decreased land surface temperatures and increased thermal atmospheric stability resulting in reduced regional precipitation.
\end{abstract}

Keywords: regional weather conditions; forest fires; Central and Eastern Siberia; COSMO-ART; modeling experiments

\section{Introduction}

Wildfires have a significant impact on the biosphere [1-5]. They lead to partial or complete destruction of natural ecosystems, death of plants and animals, loss of biodiversity, and decline in natural soil fertility [6]. Wildfires can have also significant economic and social consequences for local communities and can be harmful or even fatal for humans living in the regions close to the burning areas.

High frequency and severity of forest fires have been observed during recent decades in different regions of the world and attributed to both increased anthropogenic impacts on the biosphere and modern climate changes [1,7-12]. Rising global temperature and increased frequency, intensity, and duration of heat waves and droughts [13] are usually considered to be the main climatic factors influencing forest fire occurrence [14]. Anthropogenic factors affecting forest fire hazard include burning dry grass and debris, unattended campfires, careless use of equipment, and infrastructure development in the wildland-urban interface [15]. 
Previous studies examined relationships between wildfire and regional weather and climatic conditions, often focusing on atmospheric conditions that facilitate the occurrence of forest fires [12,16-18]. The influence of forest fires on climate and weather conditions are often considered in the context of direct wildfire impact on surface albedo, net radiation, energy and water fluxes at the land surface-atmosphere interface $[19,20]$. However, other studies also consider fire-induced increases in emissions of greenhouse gases (GHG) [21-23] and aerosols into the atmosphere [24-28]. All of these factors affect the land surface net radiation, cloud formation, and precipitation. Li et al. [29] considered the possible influence of forest fires on global temperatures by comparing fire-on and fire-off simulations with the Community Earth System Model (CESM) and showed that 20th century wildfires led mean global air temperature to increase $\approx 0.2^{\circ} \mathrm{C}$ and mean global net radiation to decrease $\approx 1 \mathrm{~W} / \mathrm{m}^{2}$. The results of numerical experiments showed that wildfires result in a significant reduction in surface evapotranspiration and increase of global runoff, but have almost no impact on annual precipitation amount [30]. Furthermore, a global analysis of biophysical feedbacks between forest fires and surface temperature showed that the mean temperature of all burned areas in the northern hemisphere one year following fires was $\approx 0.15^{\circ} \mathrm{C}$ higher than the temperature in undisturbed forest areas [5]. Reduced evapotranspiration rate in the burned areas occurs at least five years after fires and can lead to lower cloud cover in the intra-continental areas. Robock [31] analyzed the possible effects of wildfire smoke on regional weather conditions and showed that the smoke-induced reduction in atmospheric transparency can decrease daytime temperatures by up to $7^{\circ} \mathrm{C}$.

The geographical distribution of forest fires in the world is very heterogeneous mainly due to aggregated influences of regional climate, vegetation, and soil diversity [32]. Therefore, the influence of forest fires on spatial patterns of temperature, net radiation, precipitation, and clouds can be expected to significantly vary among geographical regions $[19,33,34]$. Boreal forests cover large areas in northern hemisphere and hold approximately $1 / 3$ of all land surface organic carbon reserves, including the carbon stored in peatlands [35-39]. The temperate continental climate with frequent and prolonged spells of dry and hot weather in summer months contributes to high risk of wildfire occurrence in the boreal forest. Considering the substantial carbon stocks, it is possible that wildfires in boreal forests can lead to high GHG emissions into the atmosphere compared to other regions and, thereby, can have a significant impact on the global climate system [7,40]. According to McRae et al. [9], carbon emissions from burned forests in Siberia can range from 4.8 to $15.4 \mathrm{tC} \mathrm{ha}^{-1}$ depending on the fire severity.

Although at the beginning of the 21st century there was a slight reduction in total annual burned area in boreal forest zone ( $2.0 \%$ down to $0.33 \%$ as compared to the last century) [41-43], the modern frequency of forest fires in Central and Eastern Siberia remains at a fairly high level [44,45]. Wildfires in Russia annually affect up to 14 million ha of boreal forests [9]. The highest risks of wildfire occurrences remain in the mature and old growth forest stands [46].

Given the lack of existing experimental data describing the possible influence of forest fires on local to regional atmospheric and surface conditions, regional atmospheric models can be an effective tool to derive the possible influence of wildfires on regional weather conditions. The main goal of our study was to assess the possible influences of very strong wildfires in the Central and Eastern Siberia (Russia) during the summer of 2019 on regional meteorological conditions (e.g., air temperature and humidity, precipitation, solar radiation) and surface energy fluxes. Very high intensity of forest fires in the Central and Eastern Siberia was mainly due to hot and dry weather conditions prevailing in the region since the first decade of May 2019. Effects of forest fires on regional weather conditions were derived using regional modeling system COSMO-Ru for weather forecasting and COSMO-RuART model configuration for evaluating the aerosol and reactive trace gas influence on the atmosphere. Application of the various model configurations can help to describe effects of forest fires on atmospheric properties for both the active burning period and the period following fire. 


\section{Materials and Methods}

\subsection{The Study Area and Weather Conditions during the Study Period}

Our modeling study focused on two areas situated in the Central and Eastern Siberian parts of Northern Eurasia. The first area (Area 1) was in the eastern part of the Krasnoyarsk Krai and the northern part of the Irkutsk Region, and the second one (Area 2) was in northern Yakutia (Figure 1). These areas were chosen because in 2019 they were hotspots of fire activity in Siberia. Area 1 has sporadic discontinuous permafrost and is mainly covered by boreal forest communities ( $>70 \%)$. Area 2 has continuous permafrost and is covered by boreal and tundra vegetation.

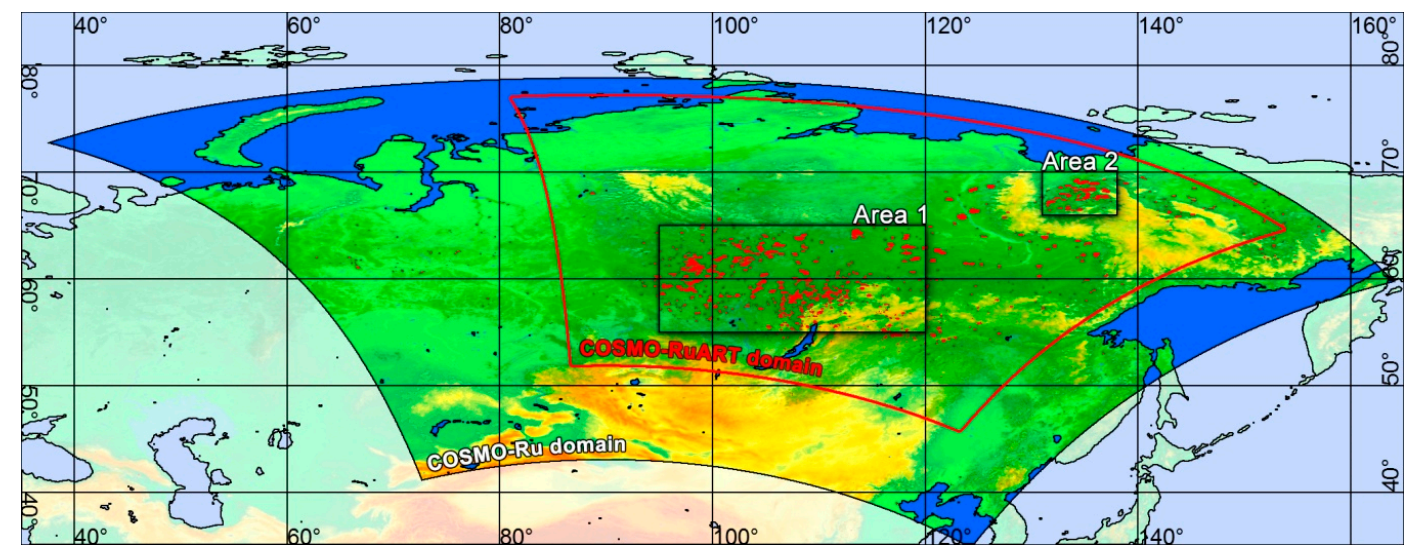

Figure 1. Geographical locations of the COSMO-Ru (COnsortium for Small-scale MOdeling; $\mathrm{Ru}$-Russia) and COSMO-RuART (ART-Aerosols and Reactive Trace gases) modeling domains (contoured by black and red lines, respectively), as well as Study Area 1 and Area 2 (contoured by blue line) selected to analyze the possible effects of forest fires on weather conditions. Red spots are locations of forest fires within the modeling domains for selected period of 1-14 August 2019. The background color depicts surface elevation.

According to the Köppen-Geiger climate classification system [47,48], Area 1 has subarctic climate (Dfc) with long and usually very cold winters with short mild summers. Area 2 is situated in the north-eastern part of the modeling domain and it is characterized by extremely cold subarctic climates (Dfd, Dwd) with severe winters and very short cool to mild summers [49,50].

To analyze the possible effects of forest fires on regional weather conditions, a two-week period from 1 to 14 August 2019 was selected. The summer of 2019 in Central and Eastern Siberia was characterized by weather conditions with prevailing high air temperatures and large precipitation deficiency. In May and June, the weather conditions in the study area were mainly influenced by high-pressure systems that provide sunny and relatively dry weather conditions. Weak precipitation was mainly associated with regional frontal and cyclonic activity. The prevailing anticyclone weather caused a significant shortage of precipitation over most of the study region. The frequent southern advections of very warm subtropical air resulted in significant positive temperature anomalies. In the northern part of Yakutia, the temperature anomalies in June reached $+8.9^{\circ} \mathrm{C}$. In July, warm weather conditions in Central and Eastern Siberia continued. Western active cyclones were blocked by stationary high-pressure areas and did not reach the study regions. This contributed to the continuing dry weather conditions in the study areas. In August, under the influence of southern winds and anticyclone weather, significant temperature anomalies developed in northern Siberia, with some regions experiencing monthly temperature anomalies that exceeded $+6{ }^{\circ} \mathrm{C}$. In addition, a lack of precipitation persisted for most areas included in the study. Precipitation rates near the long-term climatic mean were only observed in the central regions of Yakutia (to the south from the Area 2). These weather conditions highly contributed to the extremely large spread of natural fires in the vast 
forests of Central and Eastern Siberia. The total area damaged by forest fires in Siberia in August 2019 reached 13 million hectares.

\subsection{Meso-Meteorological Non-Hydrostatic Model System COSMO-RuART}

To derive the possible influence of forest fires on regional weather conditions (temperature, humidity, cloudiness, and precipitation patterns) in the Central and Eastern Siberia in 2019, we applied the model system COSMO-RuART. COSMO-RuART is a specific model configuration of the COSMO-ART (COnsortium for Small-scale MOdeling-Aerosols and Reactive Trace gases) model system that combines mesoscale weather forecast model (COSMO) with Aerosols and Reactive Trace gases (ART) atmospheric chemistry module [51]. The COSMO is a nonhydrostatic limited-area atmospheric prediction model that was developed within the framework of the Consortium for Small-Scale Modeling [52]. It is based on thermo-hydrodynamical equations describing compressible flow in a moist atmosphere and designed for operational numerical weather predictions. The land surface parameterization applied in COSMO allows for description of the energy and water exchange at the soil-vegetation-atmosphere interface while accounting for the biophysical properties of various vegetation types and changes due to external factors (e.g., wildfires). COSMO configuration for numerical weather forecasting and modeling experiments in Russia is called COSMO-Ru model system [53] and it has been used by the Hydrometeorological Center of Russia since 2009 for operational and research tasks including regional weather forecasting.

The main advantage of the COSMO-ART model system is its ability to simulate chemical transformations of gaseous substances, photodissociation, coagulation, condensation, nucleation, deposition, removal, and washing out of aerosols in the atmosphere while also taking into account the aerosol chemistry, aerosol optical properties, aerosol-radiation interaction, thermal emissions of sea salt, mineral dust and pollen, and biogenic emissions of hydrocarbons. The important feature of COSMO-ART is also its ability for joint simulations of meteorological parameters and chemical transformations at each time step that allows consideration of aerosol feedback on radiation and meteorological conditions in the atmosphere. The COSMO-RuART configuration is adapted for daily operational weather predictions using external information about pollution emissions over Russia [54]. It is especially important in regions with high aerosol concentrations in the air and is useful in areas with strong atmospheric pollution from anthropogenic sources or wildfires [55-57].

\subsection{Modeling Experiments}

The very warm and dry weather conditions observed in Siberia (Russia) in summer 2019 contributed to extreme spread of natural fires in the region's vast forested areas. The two-week period in August 2019 (1-14 August) was selected for our modeling study because of maximum fire activity in the region at this time. The spatial pattern of regional forest fires during this period was derived using the MODIS Thermal Anomalies/Fire products [58]. Assessing the volumes of GHG and aerosol emissions from wildfires into the atmosphere was provided using the methods suggested by Bondur et al. [59-61]. To predict the possible effect of forest fires on regional weather conditions, two modeling domains were selected (Figure 1). The modeling domain for COSMO-Ru covered almost the entire territory of Siberia, the north-eastern part of the Russian Far East, and the northern borders of China and Mongolia. It consisted of $735 \times 600$ simulation grid points. The COSMO-RuART modeling domain was situated within the COSMO-Ru domain and consisted of $420 \times 420$ simulation grid points. The initial and boundary conditions for the COSMO-Ru model were provided by the global nonhydrostatic numerical weather prediction model ICON (ICOsahedral Nonhydrostatic) with grid spacing of $13.2 \mathrm{~km}$ [62], whereas the boundary conditions for COSMO-RuART were determined from the COSMO-Ru calculations. The ICON forecasts on lead-time from 0 to $21 \mathrm{~h}$ were used as driving fields for regional model runs. A spectral nudging technique was applied to reduce the difference in description of large-scale circulation processes provided by regional and global models. In our modeling experiments we used the scale of the assimilated large-scale components of atmospheric 
circulations with a wavelength equal or larger than $1000 \mathrm{~km}$. The wavelength choice was based on the decomposition of the atmospheric fields of the ICON and COSMO models in a two-dimensional Fourier series with subsequent separate assimilation of large-scale waves of ICON in the COSMO model. All modeling experiments in our study were performed using the COSMO-Ru and COSMO-RuART model configurations of the COSMO 5.0 model with 40 vertical levels up to a height of $22 \mathrm{~km}$ and with horizontal grid spacing of 0.06 degrees $(\approx 6.6 \mathrm{~km})$ on the Cray XC40-LC supercomputing system located at the Main Computer Center of Roshydromet (Moscow, Russia). This model grid spacing is currently used by operational short-range numerical weather forecast system COSMO-Ru $[53,54]$ and balances forecast accuracy with computing demand.

To derive the possible response of forest fires to regional weather conditions, we conducted four numerical experiments (one control experiment and three forest fire experiments assuming total destruction of vegetation cover within the burned areas). The control experiment assumed complete absence of forest fires within and outside the modeling areas and domains. The first forest fire experiment assumed total destruction by fires of all trees within the model grids with detected forest fire locations (shown by red spots in Figure 1). Complete disappearance of above ground tree and plant biomass at the burned areas results in reduction of the forest coverage and Leaf Area Index (LAI) to zero as well as a decrease of surface albedo to $10 \%[2,63]$. The second forest fire experiment also assumed complete elimination of trees, plants, and surface litter at the burned areas, as well as stronger reduction of surface albedo to less than $1 \%$ due to dense soot deposition on the ground surface. Any possible effects of forest fires on atmosphere transparency and the release of aerosols and gaseous substances into the atmosphere in both these forest fire experiments were ignored (ART module is deactivated). Thus, the results of these two experiments can be interpreted as the possible impact of fire-induced land surface changes on the atmosphere during the period following fire until beginning active plant cover recovery. Considering a high frequency of forest fires and large areas in Siberia damaged by fire over the last decade, such scenarios can be useful for better understanding the key mechanisms of the land surface-atmosphere interactions during the post-fire period.

The last modeling experiment used parameter settings similar to the first forest fire scenario but was conducted with the activated ART module to account for all possible effects of forest fires on regional weather conditions, including changes of surface albedo, forest coverage, LAI, air chemistry, and atmospheric aerosol concentrations [54]. Thus, all combinations of direct and feedback links between forest fires and atmospheric characteristics observed at the time of the forest burning period were considered in the study. The possible effects of forest fires on surface roughness characteristics due to reduced forest LAI were ignored in the study. The modeling algorithm describing particulate matter (PM) emission into the atmosphere during the forest fires [64-66] was evaluated and showed good agreement with various atmospheric observations [54].

To conduct all our numerical experiments 576 processor cores of the Cray XC40-LC supercomputing system were used. Numerical experiments without ART module for the modeling domain with $735 \times$ $600 \times 40$ grid cells at $40 \mathrm{~s}$ time step require $\approx 450 \mathrm{~min}$ computing time for $336 \mathrm{~h}$ forecasting. The ART experiments for the domain with $420 \times 420 \times 40$ grid cells at $20 \mathrm{~s}$ time step required $\approx 1500 \mathrm{~min}$ computing time.

\subsection{Convective Instability Indexes}

To estimate the effect of forest fires on convective atmospheric conditions, we applied the Convective Available Potential Energy (CAPE) and Convective Inhibition (CIN) indices. CAPE is a measure of the amount of energy available for convection and it is directly related to the speed of an air parcel rising upward through the atmosphere. The CIN index is the opposite index to CAPE and it quantifies the energy needed to lift an air parcel upward adiabatically and pseudo-adiabatically to free convection level [67].

In our study, we used two different ways to calculate the CAPE and CIN indices $[67,68]$. The mixed level versions (MLCAPE, MLCIN) are used to calculate the indices using the parcel conditions within 
the lowest $50 \mathrm{hPa}$ atmospheric layer lifting to the level of free convection. The most unstable index versions (MUCAPE, MUCIN) are calculated from the conditions of the most unstable air parcel starting at the ground surface and ending at $300 \mathrm{hPa}$ above the surface.

\section{Results}

The results of our modeling experiments showed that the forest fires in Central and Eastern Siberia in August 2019 significantly influenced local and regional weather conditions. The fires affected both spatial and temporal variability of key meteorological parameters (air temperature and humidity, solar radiation, precipitation, cloud amount) and energy fluxes at the land surface-atmosphere interface. Fire influences were observed in both the burned areas and regions situated far away from the forest fires.

\subsection{Effect of Forest Fires on Time Averaged Meteorological Characteristics}

The modeling experiments considering the possible effects of forest fires on regional meteorological conditions due to fire-induced changes of surface properties without accounting for atmospheric chemistry and transparency changes (experiments 1 and 2) showed that the mean air temperatures at $2 \mathrm{~m}$ above the ground were about $0.2-0.3^{\circ} \mathrm{C}$ higher than the mean air temperatures in the control experiment (Table 1; Table 2). Similar comparisons of the mean air temperatures at burned sites between forest fire and control experiments showed that the differences of the mean air temperatures (at $2 \mathrm{~m}$ above the ground surface) at burned sites significantly exceeded the differences obtained for the entire areas and can reach $1.1-1.3^{\circ} \mathrm{C}$.

The results of the forest fire experiment 3 with activated ART atmospheric chemistry module showed opposite temperature trends. The mean near-surface air temperature at burned sites was $\approx 2.1^{\circ} \mathrm{C}$ lower than in the control experiment for Area 1 and $\approx 0.9^{\circ} \mathrm{C}$ lower than in the control experiment for the Area 2. Similar trends were found for the air temperature differences averaged for each modeling area (Table 1; Table 2).

Contrasting trends in the modeling experiments were also found in incoming solar and net radiation (Table 1; Table 2). Whereas in modeling experiments 1-2 the influence of forest fires on incoming solar radiation was quite insignificant, their effect in the ART experiment was much larger (Table 1; Table 2). It was shown that in Area 1, the decrease of direct solar radiation in the ART experiment due to forest fires reached $67 \%$, while the direct solar radiation reduction in the Area 2, situated further northeast, was only $54 \%$. The maximum changes in diffuse solar radiation in the ART experiment was found in Area 2 (56\%) whereas changes for Area 1 were lower at $43 \%$.

The differences in fire-induced changes of incoming solar radiation and albedo cause changes in shortwave net radiations for the various modeling experiments. In the first two forest fire experiments increasing shortwave net radiation was due to reduced albedo, but the decrease of the shortwave net radiation in the ART experiment was mainly due to reduced incoming solar radiation caused by wildfire smoke. The shortwave net radiation reduction reached 32\% for Area 1 and $16 \%$ for Area 2. The changes of net radiation due to forest fires had similar trends, except for the first forest fire experiment, where a slight decrease of the surface net radiation compared to the control experiment was found.

One of the key results obtained during the modeling experiments was that fire decreased latent heat fluxes up to $92 \%$ compared with control conditions, which was due to $100 \%$ reduction of transpiration-mediated water loss by plants at burned sites. Strongly decreased latent and increased sensible heat fluxes also caused a significant increase of the Bowen ratio, with values reaching a maximum for Area 2 (up to 16 in experiment 2) (Table 1; Table 2).

Reduction of evapotranspiration in burned areas decreased near surface air specific humidity, dew points, and partial pressure of water vapor (Table 1; Table 2). The specific humidity at $2 \mathrm{~m}$ above ground was up to $0.6^{\circ} \mathrm{C}$ lower at burned sites for all forest fire experiments compared with the control. Analysis of the relative humidity changes in the ART experiment indicated that the small increases 
in both model areas were mainly due to significantly reduced near-surface air temperature despite decreased specific humidity.

Table 1. Mean values of meteorological parameters for the entire Area 1 (A1) and burned sites within the Area 1 (Figure 1) from 1 to 14 August 2019 derived from forest fire experiments.

\begin{tabular}{|c|c|c|c|c|c|c|c|c|}
\hline \multirow{2}{*}{$\begin{array}{l}\text { Meteorological } \\
\text { Parameters }\end{array}$} & \multicolumn{2}{|c|}{ Control Experiment } & \multicolumn{2}{|c|}{$\begin{array}{c}\text { Forest Fire } \\
\text { Experiment } 1 \\
\text { (without ART) }\end{array}$} & \multicolumn{2}{|c|}{$\begin{array}{c}\text { Forest Fire } \\
\text { Experiment } 2 \\
\text { (without ART) }\end{array}$} & \multicolumn{2}{|c|}{$\begin{array}{c}\text { Forest Fire } \\
\text { Experiment } 3 \\
\text { (with ART) }\end{array}$} \\
\hline & A1 & $\begin{array}{l}\text { Sites Damaged } \\
\text { by Fires in } \\
\text { Experiments 1-3 }\end{array}$ & A1 & $\begin{array}{l}\text { Burned } \\
\text { Sites }\end{array}$ & A1 & $\begin{array}{l}\text { Burned } \\
\text { Sites }\end{array}$ & A1 & $\begin{array}{c}\text { Burned } \\
\text { Sites }\end{array}$ \\
\hline Surface albedo, $\%$ & 12.8 & 13.1 & 12.6 & 10.0 & 11.7 & 0.02 & 12.6 & 10.0 \\
\hline $\begin{array}{l}\text { Air temperature at } \\
2 \mathrm{~m} \text { height, }{ }^{\circ} \mathrm{C}\end{array}$ & 17.1 & 17.6 & 17.3 & 18.7 & 17.4 & 18.9 & 15.1 & 15.7 \\
\hline $\begin{array}{l}\text { Dew point at } 2 \mathrm{~m} \\
\text { height, }{ }^{\circ} \mathrm{C}\end{array}$ & 11.6 & 11.5 & 11.3 & 10.5 & 11.3 & 10.4 & 10.8 & 10.2 \\
\hline $\begin{array}{l}\text { Dew point deficit } \\
\text { at } 2 \mathrm{~m} \text { height, }{ }^{\circ} \mathrm{C}\end{array}$ & 5.5 & 6.1 & 6 & 8.2 & 6.1 & 8.5 & 4.3 & 5.5 \\
\hline $\begin{array}{l}\text { Partial pressure of } \\
\text { water vapor, } \mathrm{hPa}\end{array}$ & 13.7 & 13.6 & 13.4 & 12.7 & 13.4 & 12.6 & 12.9 & 12.4 \\
\hline $\begin{array}{l}\text { Specific humidity } \\
\text { at } 2 \mathrm{~m} \text { height, } \mathrm{g} / \mathrm{kg}\end{array}$ & 9.0 & 8.9 & 8.8 & 8.3 & 8.8 & 8.3 & 8.5 & 8.2 \\
\hline $\begin{array}{c}\text { Wind speed at } \\
10 \mathrm{~m} \text { height, } \mathrm{m} / \mathrm{s}\end{array}$ & 2.3 & 2.3 & 2.3 & 2.5 & 2.3 & 2.6 & 2.2 & 2.3 \\
\hline $\begin{array}{l}\text { Surface sensible } \\
\text { heat flux, } \mathrm{W} / \mathrm{m}^{2}\end{array}$ & 26.6 & 31.0 & 29.3 & 77.8 & 30.0 & 91.8 & 14.1 & 39.1 \\
\hline $\begin{array}{l}\text { Surface latent heat } \\
\text { flux, } \mathrm{W} / \mathrm{m}^{2}\end{array}$ & 74.0 & 67.9 & 70.4 & 14.5 & 71.1 & 15.3 & 49.0 & 11.2 \\
\hline Bowen ratio & 0.4 & 0.5 & 0.4 & 5.4 & 0.4 & 6.0 & 0.3 & 3.5 \\
\hline $\begin{array}{c}\text { Direct shortwave } \\
\text { radiation at } \\
\text { ground surface, } \\
\mathrm{W} / \mathrm{m}^{2}\end{array}$ & 135 & 136 & 136 & 136 & 137 & 137 & 45 & 36 \\
\hline $\begin{array}{l}\text { Diffuse shortwave } \\
\text { radiation at } \\
\text { ground surface, } \\
\mathrm{W} / \mathrm{m}^{2}\end{array}$ & 73 & 73 & 73 & 72 & 73 & 68 & 105 & 99 \\
\hline $\begin{array}{l}\text { Shortwave net } \\
\text { radiation, } \mathrm{W} / \mathrm{m}^{2}\end{array}$ & 181 & 181 & 183 & 187 & 185 & 205 & 132 & 122 \\
\hline $\begin{array}{l}\text { Net radiation, } \\
\mathrm{W} / \mathrm{m}^{2}\end{array}$ & 110 & 109 & 110 & 105 & 111 & 120 & 70 & 59 \\
\hline $\begin{array}{l}\text { Low-level cloud } \\
\text { cover, } \%\end{array}$ & 24 & 22 & 22 & 21 & 22 & 20 & 28 & 27 \\
\hline $\begin{array}{l}\text { Mid-level cloud } \\
\text { cover, } \%\end{array}$ & 28 & 27 & 28 & 27 & 28 & 27 & 26 & 25 \\
\hline $\begin{array}{l}\text { High-level cloud } \\
\text { cover, } \%\end{array}$ & 46 & 45 & 45 & 45 & 45 & 45 & 35 & 35 \\
\hline $\begin{array}{c}\text { Total cloud cover, } \\
\%\end{array}$ & 57 & 56 & 56 & 56 & 56 & 56 & 53 & 52 \\
\hline $\begin{array}{l}\text { Total precipitation } \\
\text { for the entire } \\
\text { period, } \mathrm{mm}\end{array}$ & 30.5 & 30.8 & 30.0 & 31.6 & 30.2 & 32.0 & 23.0 & 22.3 \\
\hline
\end{tabular}

The models showed that the possible effect of forest fires on wind speed due to total vegetation destruction at burned sites did not have a significant effect on modeled mean wind speed values 
(Table 1; Table 2). A small increase in wind speed $\left(0.1-0.3 \mathrm{~m} \mathrm{~s}^{-1}\right)$ was only detected at the completely burned areas in the forest fire experiments 1 and 2.

Table 2. Mean values of meteorological parameters for the entire Area 2 (A2) and burnt sites within the Area 2 (Figure 1) from 1 to 14 August 2019 derived from various forest fire experiments.

\begin{tabular}{|c|c|c|c|c|c|c|c|c|}
\hline \multirow{2}{*}{$\begin{array}{c}\text { Meteorological } \\
\text { Parameters }\end{array}$} & \multicolumn{2}{|c|}{ Control Experiment } & \multicolumn{2}{|c|}{$\begin{array}{c}\text { Forest Fire } \\
\text { Experiment } 1 \\
\text { (without ART) }\end{array}$} & \multicolumn{2}{|c|}{$\begin{array}{c}\text { Forest Fire } \\
\text { Experiment } 2 \\
\text { (without ART) }\end{array}$} & \multicolumn{2}{|c|}{$\begin{array}{l}\text { Forest Fire } \\
\text { Experiment } 3 \\
\text { (with ART) }\end{array}$} \\
\hline & A2 & $\begin{array}{l}\text { Sites Damaged } \\
\text { by Fires in } \\
\text { Experiments 1-3 }\end{array}$ & A2 & $\begin{array}{l}\text { Burned } \\
\text { Sites }\end{array}$ & A2 & $\begin{array}{l}\text { Burned } \\
\text { Sites }\end{array}$ & A2 & $\begin{array}{c}\text { Burned } \\
\text { Sites }\end{array}$ \\
\hline Surface albedo, $\%$ & 11.4 & 12.3 & 11.2 & 10.0 & 9.8 & 0.02 & 11.2 & 10.0 \\
\hline $\begin{array}{l}\text { Air temperature at } \\
2 \mathrm{~m} \text { height, }{ }^{\circ} \mathrm{C}\end{array}$ & 13.4 & 13.9 & 13.6 & 14.7 & 13.7 & 15.1 & 12.3 & 13.2 \\
\hline $\begin{array}{l}\text { Dew point at } 2 \mathrm{~m} \\
\text { height, }{ }^{\circ} \mathrm{C}\end{array}$ & 7.4 & 7.3 & 7.1 & 6.3 & 7.1 & 6.2 & 6.8 & 6.0 \\
\hline $\begin{array}{l}\text { Dew point deficit } \\
\text { at } 2 \mathrm{~m} \text { height, }{ }^{\circ} \mathrm{C}\end{array}$ & 6 & 6.6 & 6.5 & 8.4 & 6.6 & 8.9 & 5.5 & 7.2 \\
\hline $\begin{array}{l}\text { Partial pressure of } \\
\text { water vapor, } \mathrm{hPa}\end{array}$ & 10.3 & 10.2 & 10.1 & 9.5 & 10.1 & 9.5 & 9.9 & 9.3 \\
\hline $\begin{array}{l}\text { Specific humidity } \\
\text { at } 2 \mathrm{~m} \text { height, } \mathrm{g} / \mathrm{kg}\end{array}$ & 6.8 & 6.7 & 6.6 & 6.3 & 6.6 & 6.2 & 6.5 & 6.1 \\
\hline $\begin{array}{l}\text { Wind speed at } \\
10 \mathrm{~m} \text { height, } \mathrm{m} / \mathrm{s}\end{array}$ & 2.3 & 2.2 & 2.4 & 2.3 & 2.4 & 2.4 & 2.1 & 2.1 \\
\hline $\begin{array}{l}\text { Surface sensible } \\
\text { heat flux, } \mathrm{W} / \mathrm{m}^{2}\end{array}$ & 34.9 & 39.3 & 37.4 & 71.2 & 40.3 & 88.3 & 24.8 & 48.7 \\
\hline $\begin{array}{l}\text { Surface latent heat } \\
\text { flux, } \mathrm{W} / \mathrm{m}^{2}\end{array}$ & 50.0 & 46.6 & 45.4 & 5.7 & 45.9 & 5.6 & 34.2 & 3.5 \\
\hline Bowen ratio & 0.7 & 0.8 & 0.8 & 12.5 & 0.9 & 15.8 & 0.7 & 13.9 \\
\hline $\begin{array}{c}\text { Direct shortwave } \\
\text { radiation at } \\
\text { ground surface, } \\
\mathrm{W} / \mathrm{m}^{2}\end{array}$ & 138 & 148 & 138 & 146 & 141 & 146 & 63 & 65 \\
\hline $\begin{array}{c}\text { Diffuse shortwave } \\
\text { radiation at } \\
\text { ground surface, } \\
\mathrm{W} / \mathrm{m}^{2}\end{array}$ & 70 & 67 & 69 & 66 & 68 & 62 & 109 & 109 \\
\hline $\begin{array}{l}\text { Short-wave net } \\
\text { radiation, } \mathrm{W} / \mathrm{m}^{2}\end{array}$ & 182 & 185 & 181 & 189 & 186 & 208 & 152 & 156 \\
\hline $\begin{array}{l}\text { Net radiation, } \\
\mathrm{W} / \mathrm{m}^{2}\end{array}$ & 100 & 101 & 99 & 96 & 103 & 114 & 72 & 68 \\
\hline $\begin{array}{l}\text { Low-level cloud } \\
\text { cover, } \%\end{array}$ & 20 & 17 & 19 & 17 & 18 & 17 & 17 & 14 \\
\hline $\begin{array}{l}\text { Mid-level cloud } \\
\text { cover, } \%\end{array}$ & 28 & 25 & 28 & 26 & 27 & 26 & 22 & 19 \\
\hline $\begin{array}{l}\text { High-level cloud } \\
\text { cover, } \%\end{array}$ & 27 & 26 & 27 & 27 & 28 & 27 & 17 & 16 \\
\hline $\begin{array}{l}\text { Total cloud cover, } \\
\%\end{array}$ & 48 & 44 & 47 & 44 & 46 & 45 & 39 & 34 \\
\hline $\begin{array}{l}\text { Total precipitation } \\
\text { for the entire } \\
\text { period, } \mathrm{mm}\end{array}$ & 7.6 & 5.2 & 7.4 & 6.3 & 7.2 & 5.5 & 2.5 & 1.7 \\
\hline
\end{tabular}

Significant differences were found between various modeling experiments to derive forest fire influence on cloud cover and precipitation. Forest fire experiments 1 and 2 did not include aerosol and gaseous component changes in the atmosphere due to forest fires and predict relatively small decrease of total clouds amount and spatially averaged precipitation rates. On the other hand, the ART forest fire experiment forecasted a reduction of total precipitation by about $7.5 \mathrm{~mm}(24 \%)$ for modeling Area 1, and by about $5.1 \mathrm{~mm}(67 \%)$ for modeling Area 2, respectively (Table 1; Table 2). It is important 
to note that the influence of forest fire smoke on cloud amount manifests differently for cloudiness at different levels in the atmosphere. The ART experiment showed that whereas these forest fires decreased mid- and high-level cloud cover, the opposite trends were found for low-level cloud cover in different modeling areas (increases of cloud amount for the Area 1 and decreases for Area 2).

\subsection{Temporal Variability of Meteorological Parameters}

Analysis of the temporal variability of meteorological conditions for different forest fire modeling experiments showed high variability depending on time of day and weather conditions (Figure 2). The $2 \mathrm{~m}$ air temperatures averaged over each modeling area in the forest fire experiments 1 and 2 were always higher than the temperatures in the control experiments, whereas the air temperatures obtained in the ART experiment were lower than in the control, especially during the periods with high aerosol concentrations. Maximum air temperature differences between the forest fire and control experiments were found at burned sites (Figure 1) for daytime periods (up to $7^{\circ} \mathrm{C}$ ) while minimum differences occurred at nighttime (Figure $2 b$ ). Moreover, the temperature differences increased under sunny conditions and decreased under cloudy weather conditions. The temperature differences between forest fire and control experiments for the entire Areas 1 and 2 were smaller but sometimes reached $-6^{\circ} \mathrm{C}$ for the ART experiment (Figure 2a).

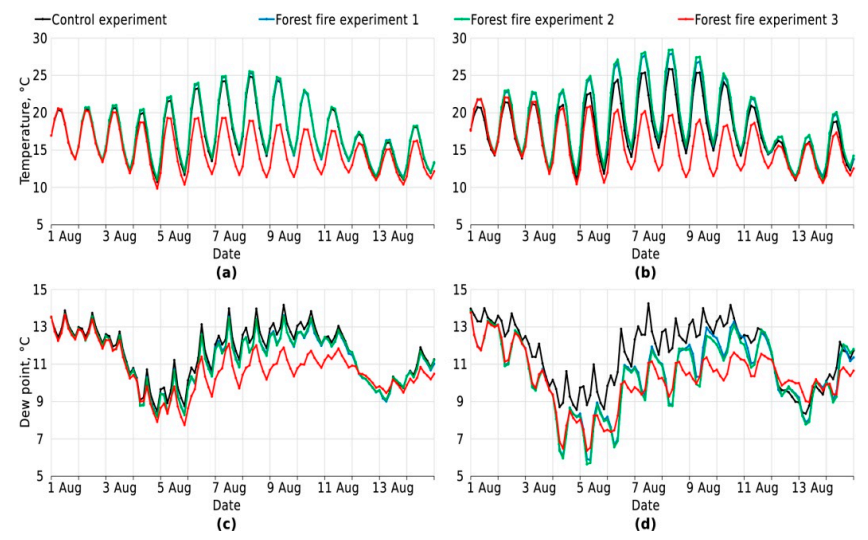

Figure 2. Temporal variability of air temperature and dew point for Area 1 from 1-14 August 2019 under various forest fire experiments: (a) mean air temperature $\left(2 \mathrm{~m}\right.$ height) for the entire area, ${ }^{\circ} \mathrm{C}$; (b) mean air temperature at the burned sites, ${ }^{\circ} \mathrm{C}$; (c) mean dew point $\left(2 \mathrm{~m}\right.$ height) for the entire area, ${ }^{\circ} \mathrm{C}$; (d) mean dew point at burned sites, ${ }^{\circ} \mathrm{C}$.

The temporal variability of dew points at $2 \mathrm{~m}$ above ground (Figure $2 \mathrm{c}, \mathrm{d}$ ) was characterized by similar variation, with maximum differences between forest fire and control experiments during the daytime and with minimum differences found at night.

Analysis of temporal variability of latent heat fluxes for various modeling experiments showed that the maximum reduction of latent heat fluxes at burned sites occurred during the day (Figure 3) when the latent heat fluxes at these sites were close to zero, even at noon. Simulated small increases of the latent heat fluxes at burned sites in the Area 1 on August 12-14 (Figure 3d) could be due to several short-term rainfalls observed during the period in parts of the study area (with maximum precipitation rate on August 12). The sensible heat fluxes at the burned sites for experiments 1 and 2 were always higher than the flux values obtained for the control experiment over the daytime period. The sensible heat fluxes obtained in the last forest fire experiment that considered aerosol-radiation interaction (with ART) for burned sites was close to the values of the control experiment (Figure $3 b$ ) and varied significantly depending on weather conditions. The mean daily sensible fluxes averaged for each modeling area obtained within the ART experiments were always significantly lower than the fluxes in the control experiment. 


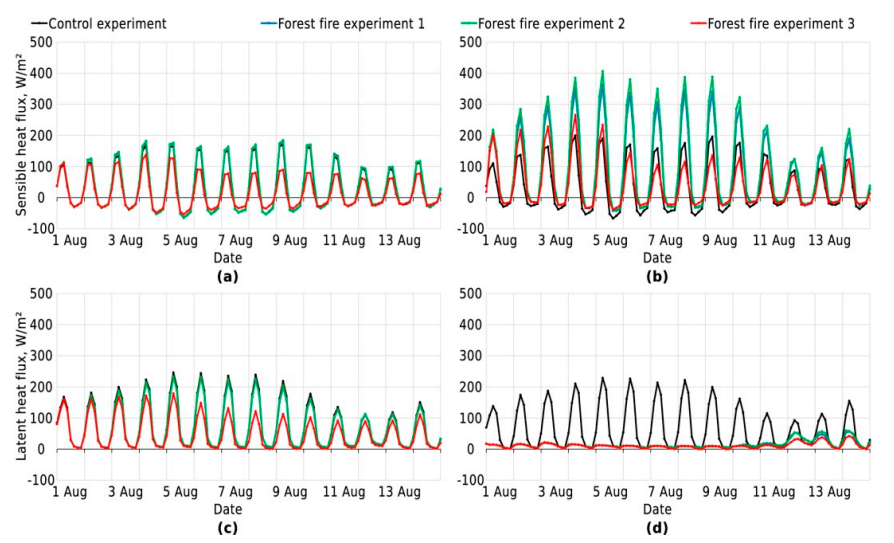

Figure 3. Temporal variability of energy fluxes for Area 1 from 1-14 August 2019 for various forest fire experiments: (a) sensible heat fluxes averaged over the entire area, $\mathrm{W} / \mathrm{m}^{2} ;$ (b) mean sensible heat fluxes at burned sites, $\mathrm{W} / \mathrm{m}^{2} ;$ (c) latent heat fluxes averaged over the entire area, $\mathrm{W} / \mathrm{m}^{2} ;(\mathbf{d})$ mean latent heat fluxes at burned sites, $\mathrm{W} / \mathrm{m}^{2}$.

\subsection{Spatial Distribution of Meteorological Parameters}

The spatial patterns of the meteorological parameter differences in various modeling experiments were mainly influenced by spatial distribution of forest fires (Figure 1) and prevailing wind direction. Figure 4 illustrates the modeled spatial distribution of biomass burning aerosol optical depth (AOD) averaged from August 1-14. The highest values of AOD were concentrated over Area 1. The AOD values over the Area 2 were lower due to aerosol transfer by prevailing eastern winds.

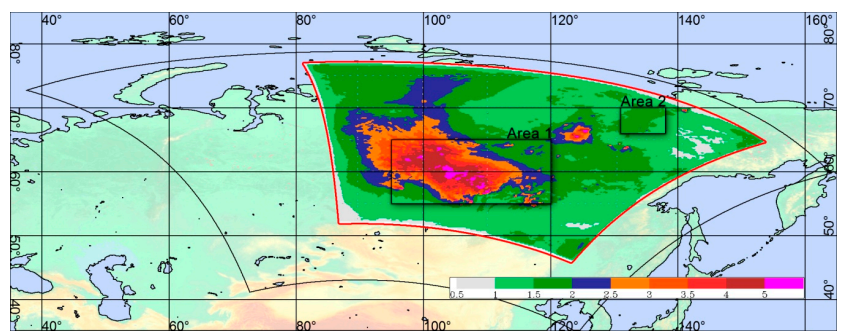

Figure 4. Modeled aerosol optical depth over the modeling domain, averaged from 1-14 August 2019.

Analysis of air temperature differences at $2 \mathrm{~m}$ above the ground between the forest fire and control experiments (Figure 5) showed that whereas the maximum temperature differences in the forest fire experiments 1 and 2 were situated close to the burning sites (Figure 1), the temperature differences in the forest fire experiment with the ART module were mainly caused by the spatial distribution of AOD (Figure 4).

Effect of forest fires on precipitation patterns was mainly influenced by global and regional circulation processes that resulted in numerous local positive and negative anomalies of precipitation rates even in areas far from burned areas (Figure 6).

Analysis of the spatial heterogeneity of convective storm indices (illustrating effects of forest fires on both near-ground surface characteristics and parameters of the entire atmosphere column) for the first two forest fire experiments ignoring aerosol and smoke influence on atmosphere properties (ART-off experiment) showed relatively small effects of forest fires on the spatial patterns of CAPE values. The absolute CAPE values in burned areas were much smaller than the values confined to the areas of atmospheric fronts with intensive upward air motions. The areas with positive CAPE values were similarly detected in all modeling experiments, although CAPE can be quite different among various experiments for some grid points and time intervals. Modeling results also show that the ART experiment provides substantially lower MLCAPE and MUCAPE values compared with ART-off experiments. There was a slight decrease in the values of these indices in the ART experiment, 
taking into account the influence of smoke on atmospheric properties, which is consistent with the trend of reduced precipitation. Similar analysis of the spatial patterns of the CIN values did not reveal any statistically significant differences among various numerical experiments.

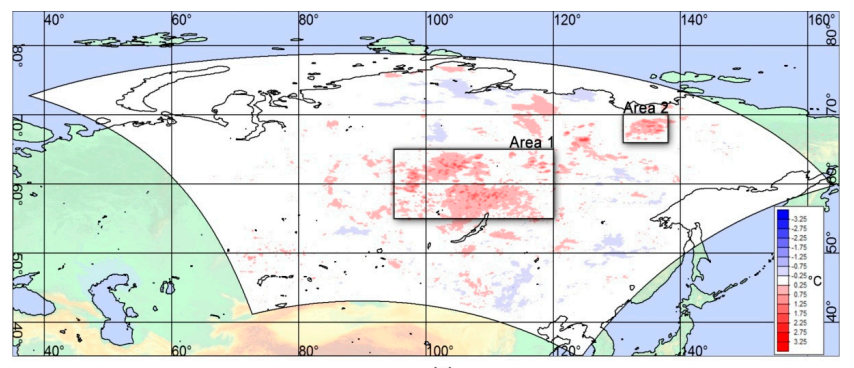

(a)

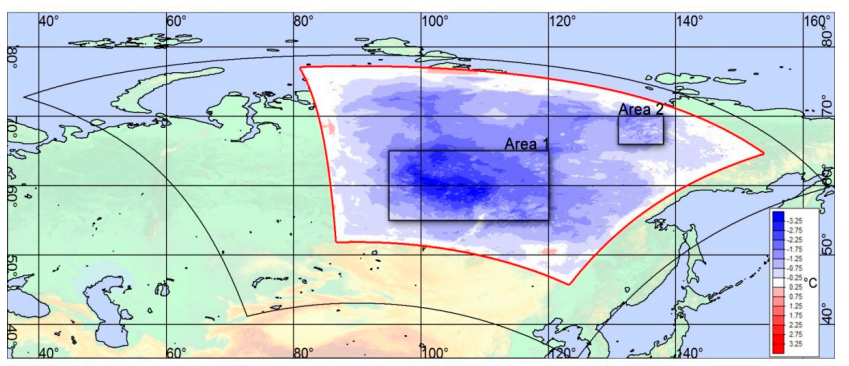

(b)

Figure 5. Spatial distribution of mean air temperature differences at $2 \mathrm{~m}$ height from 1-14 August 2019:

(a) between forest fire experiment 2 (without ART) and control experiment, (b) between forest fire experiment 3 (with ART) and control experiment.

An increase of low-level cloud cover and relative humidity near the ground (reduced dew point deficit) in the ART experiments (Table 1; Table 2) showed that the smoke from forest fires resulted in the formation of thermal inversions in the lower atmosphere. It was confirmed by a slight decrease in the convective instability of the atmosphere for the ART experiments, which can be seen in regions situated even away from forest fires (Figure 7).
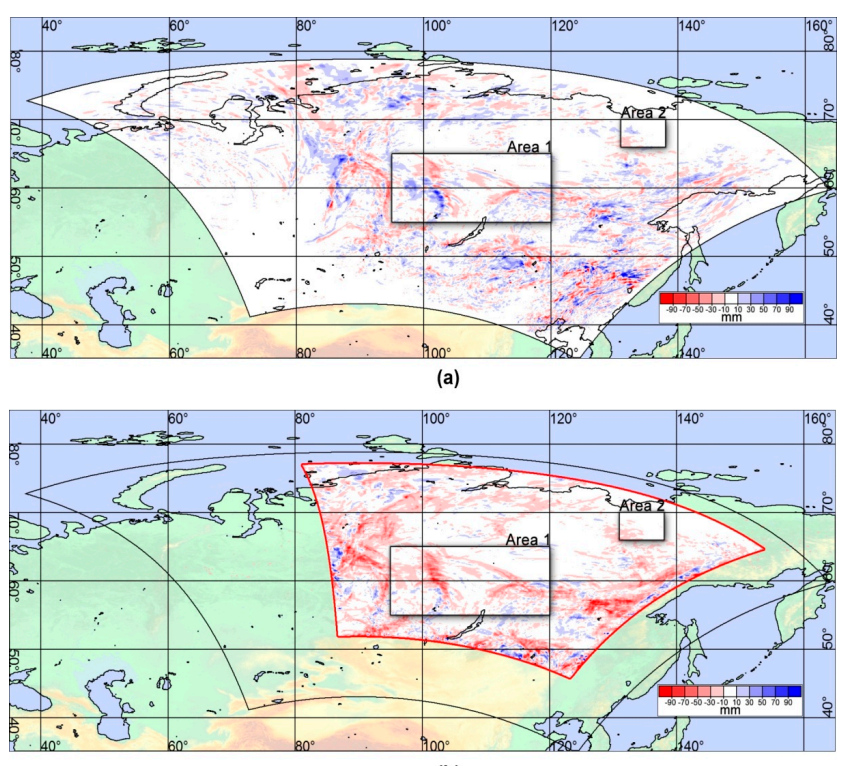

(b)

Figure 6. Spatial distribution of accumulated precipitation difference (mm) from 1-14 August 2019: (a) between forest fire experiment 1 (without ART) and control experiment, (b) between forest fire experiment 3 (with ART) and control experiment. 

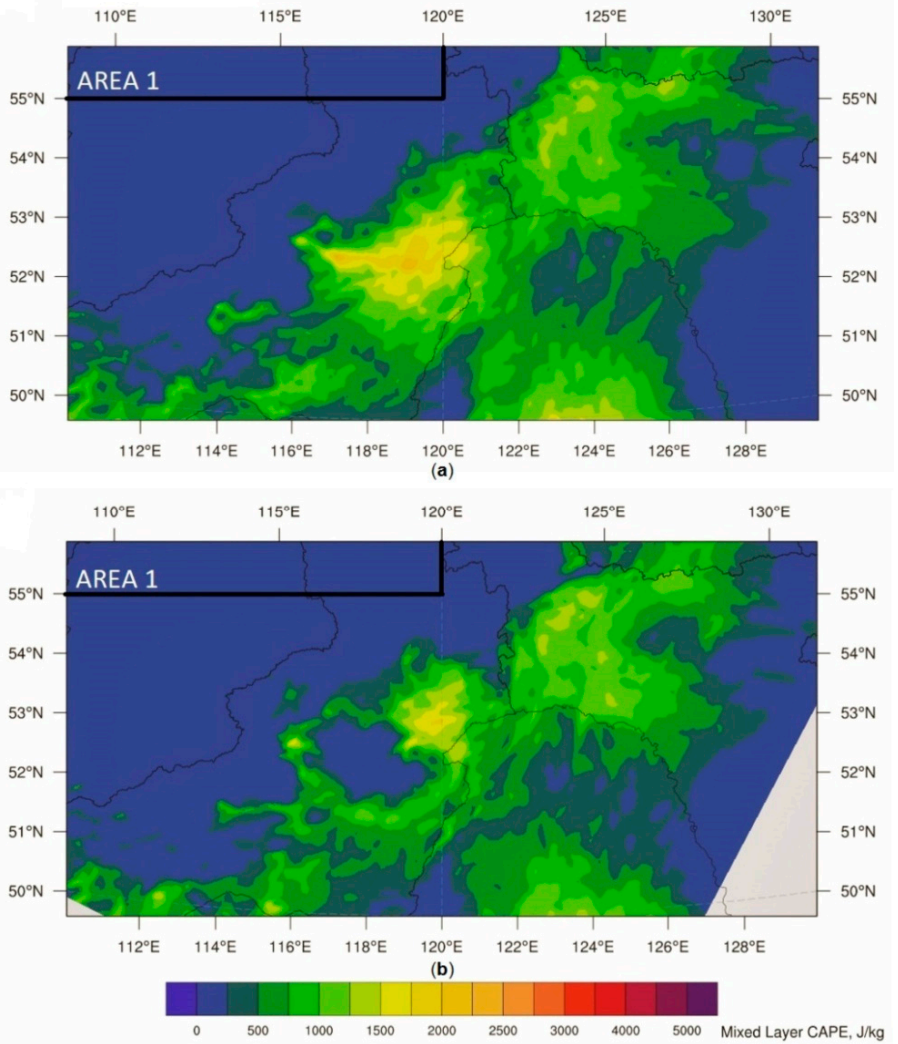

Figure 7. Spatial distributions of MLCAPE index within the area with intensive convection for: (a) control experiment and (b) ART experiment.

\section{Discussion}

The modeling scenarios illustrating different ways that forest fires can influence regional weather conditions showed a significant effect of forest fires on temporal and spatial variability of near-surface air temperature, air humidity, dew point, cloud cover, and precipitation rates. Depending on the forest fire experiment these influences had either positive or negative impacts on corresponding meteorological characteristics depending on forest fire locations, their severity, and regional atmosphere circulation features.

The first two forest fire scenarios considered the influence of forest fires on ground surface vegetation without allowing for any changes of atmospheric properties and chemistry due to significant aerosols and gases emission into the atmosphere from wildfires. Fire-induced total forest disturbance, loss of living aboveground biomass, and decrease of the surface albedo resulted in increased short-wave surface net radiation, as well as in a reduction of the latent heat flux and increase of sensible heat fluxes at burned sites. This can lead to stronger heating of the soil surface during the daytime hours, higher daytime air temperatures, and lower specific humidity of the air. Significant changes in atmospheric fluxes and the Bowen ratio at burned sites during the modeling experiments is consistent with available results of the energy balance measurements across the western boreal zone of North America [69] and shows a strong increase in the daily Bowen ratio values up to 2 and higher at boreal forest sites immediately after a fire. Similar changes in atmospheric fluxes at burned sites were obtained also by Moelder and Kramm [70] using the mesoscale model MM5 to describe wildfire effects on regional weather conditions in Alaska. They reported that increased sensible heat fluxes at burned sites due to lower albedo and higher net radiation lead to an increase of the air temperature at the sites up to $3{ }^{\circ} \mathrm{C}$. Post-fire regeneration of woody vegetation at burned sites depends on pre-burn vegetation, fire types and severity [71] and can continue for decades to centuries [72]. Active recovery of grassy vegetation at completely disturbed forest sites can increase surface albedo and evapotranspiration, 
thereby compensating for the changes in surface energy balance caused by destruction of the forest woody vegetation $[73,74]$.

The spatial precipitation patterns in the modeling scenarios that did not consider fire emission into the atmosphere are mainly influenced by global and regional circulation processes and manifested mainly in local positive or negative precipitation anomalies (Figure 6). There was a small decrease in precipitation rates that was influenced by multiple factors, including decreased evapotranspiration rate at burned sites due to forest disturbances. Similar effects were observed in the modeling experiments imitating total forest disturbances due to clear-felling conducted using the COSMO-Ru model for European part of Russia [75-77]. The effects of forest fires of spatial precipitation patterns can also be seen in a study showing a small increase in the precipitation rate in the areas situated on the leeward sides of the burned areas, as well as some precipitation reduction within the burned areas themselves [70]. Such effects were not found in our study, possibly due to numerous forest fire locations chaotically distributed within the modeling areas. Moreover, it can be expected that such different results can be explained also by various sizes of burned areas, the different durations of forest fires and their intensity. The spatial precipitation pattern can be also strongly influenced by regional and local circulation processes.

In the modeling experiments assuming a large aerosol emission into the atmosphere from the burning forest (ART experiment), we obtained opposite effects of forest fires on air temperature compared with the forest fire experiments 1 and 2 (without ART). Decreased incoming solar radiation due to increased atmospheric aerosol concentration and reduced atmospheric transparency resulted in significant decreased incoming solar radiation and near-surface air temperatures compared with the control experiment, both at burned and burning areas and at the areas far from the forest fire regions. Similar reduction of incoming solar radiation due to high smoke aerosol concentrations in the atmosphere in the areas situated at various distances from wildfire regions were also observed in numerous experimental studies [55,57,78-80].

Releases of large amounts of cloud condensation nuclei $(\mathrm{CCN})$ into the atmosphere lead to reduction of total precipitation and total cloud amount within both modeling areas. It can be expected that the fire-induced surface cooling and the heating of the atmosphere at the height of $1.5-3 \mathrm{~km}$ resulted in the weakening of the convective processes and reduced the total cloudiness and precipitation within the study area. A predicted $5 \%$ increase of low-level cloud cover (below $\approx 1.5 \mathrm{~km}$ ) over Area $1 \mathrm{did}$ not have any noticeable effect on precipitation rate since precipitation is mainly produced by multilevel and convective clouds. Similar results were obtained by Grell et al. [81] in Alaska using the WRF-Chem model. That study showed that fire-induced aerosol emissions (PM2.5) lead to significant changes in the vertical temperature and specific humidity distributions. Higher $\mathrm{CCN}$ in the air causes changes to cloud structure that in turn decrease the area and intensity of precipitation. It was also shown to increase convective heavy rainfall in the afternoon. Similar effects of forest fires on convective processes were reported in other studies [82-84]. Zhang et al. [84] used a modified WRF-Chem model to show that both heat and aerosol effects increase low-level temperatures and mid-level buoyancy and enhance consequently the convective intensity. Such effects in our study manifested in changes of the CAPE and CIN indices. Some of the differences found between the spatial patterns of the indices in various experiments with and without activated ART module could be due to differences in low-level temperatures and in energy available for free convection. It can be expected that in order to better assess the impact of forest fires on convective processes at a local scale, the simulations with models that include higher spatial resolution are very necessary.

The present study assumed that all observed forest fires in the Siberian region in 2019 were crown forest fires where the fire burns trees up their entire length to the top. More detailed information about the type of forest fires (e.g., crown, surface, ground fires) and their severity within the study areas was not available due to the remoteness from any settlements and roads. Forest fires of different types will result in different forest disturbances and have various impacts on forest albedo, net radiation, surface energy, and water budgets and this is one of the key sources of possible uncertainties in modeling 
experiments. Other possible sources of uncertainty include model simplifications in the description of the land surface-atmosphere interactions and a lack of representative input data describing particularly vegetation and soil properties in the region. One factor that should also be considered is the spatial permafrost patterns. The permafrost depth and the thickness of active surface layer can influence forest fire patterns and severity. At the same time, forest fires can be also an important driver of permafrost thaw in boreal forest zone $[85,86]$.

There are a wide range of possible weather responses to forest fires at different time and spatial scales, highlighting the need for new integrated experiments using different regional models based on detailed parameterization of cloud formation processes, aerosol exchange, solar and long-wave radiation transfer, radiation, and energy budgets of the ground surface. This will help describe in more detail how fire type (e.g., crown, surface, ground fires) and intensity affect near-surface meteorological characteristics in different regions of the world. To estimate the effect of accounting for forest fires in Numerical Weather Prediction (NWP) operational forecasts it will be necessary to conduct in-depth comparisons of different simulation scenarios with observations.

\section{Conclusions}

Our numerical experiments based on the COSMO-Ru and COSMO-RuART models revealed that forest fires affected regional weather in the Central and Eastern Siberia (Russia) for a two-week period in summer 2019. These models showed a multifaceted effect of forest fires on regional weather conditions. Forest fires significantly increased surface net radiation due to lower albedo at burned sites, as well as caused strong reduction in latent heat and increased sensible heat fluxes. Decreased evapotranspiration results in relatively small decreases in total regional precipitations that were roughly proportional to the fraction of total forest area that was damaged by fires. The spatial precipitation patterns were very heterogeneous due to regional circulation processes and characterized by numerous local positive or negative anomalies.

A large amount of aerosols released into the atmosphere from forest fires significantly decreased incoming solar and net radiations, and consequently decreased the surface temperature at both burned sites and areas situated away from the forest fires. Despite the release of large CCN amounts into the atmosphere, our modeling simulations predicted a reduction in total precipitation and total cloud amount mainly due to the fire-induced surface cooling and the heating of the atmosphere at the height of $1.5-3 \mathrm{~km}$ that lead to a weakening of the convective processes.

To determine how large forest fires affect regional weather conditions and the atmosphere under modern and future climate conditions, more accurate assessment is needed. It is important to consider the projected significant increase in air temperature in boreal and polar regions of Northern Eurasia and Northern America over the 21st century because they can lead to higher risks of forest fires [87]. Additional experimental and modeling studies describing the effect of forest fires on the atmosphere under present and projected future climate conditions are necessary.

Author Contributions: A.K., I.R., A.O. and G.R. conceived and designed the numerical experiments. A.K. performed experiments. A.K. and D.Z. analyzed data with guidance from I.R. and G.R., A.K. and A.O. wrote the paper. A.O. and I.R. edited and finalized the manuscript. All authors have read and agreed to the published version of the manuscript.

Funding: Algorithms to assess the vertical profiles of atmospheric pollutant concentrations were developed by A.K. with support by the grant of the Russian Science Foundation 16-17-10275. Analysis of forest fire impacts on regional weather conditions provided by G.R., I.R., D.Z. and A.O. was supported by grants of Federal Service for Hydrometeorology and Environmental Monitoring (AAAA-A20-120021490079-3) and Lomonosov Moscow State University (AAAA-A16-116032810086-4).

Acknowledgments: The authors acknowledge Mikhail Nikitin (Hydrometeorological Research Center of Russian Federation) for his assistance with numerical experiments. English language editing was provided by EcoSpatial Services L.L.C. (USA).

Conflicts of Interest: The authors declare no conflict of interest. 


\section{References}

1. Flannigan, M.; Stocks, B.; Wotton, B. Climate change and forest fires. Sci. Total. Environ. 2000, 262, $221-229$. [CrossRef]

2. Randerson, J.T.; Liu, H.; Flanner, M.G.; Chambers, S.D.; Jin, Y.; Hess, P.G.; Pfister, G.; Mack, M.C.; Treseder, K.K.; Welp, L.R.; et al. The Impact of Boreal Forest Fire on Climate Warming. Science 2006, 314, 1130-1132. [CrossRef] [PubMed]

3. Bonan, G.B. Forests and Climate Change: Forcings, Feedbacks, and the Climate Benefits of Forests. Science 2008, 320, 1444-1449. [CrossRef] [PubMed]

4. De Groot, W.J.; Cantin, A.S.; Flannigan, M.D.; Soja, A.J.; Gowman, L.M.; Newbery, A. A comparison of Canadian and Russian boreal forest fire regimes. For. Ecol. Manag. 2013, 294, 23-34. [CrossRef]

5. Liu, Z.; Ballantyne, A.P.; Cooper, L.A. Biophysical feedback of global forest fires on surface temperature. Nat. Commun. 2019, 10, 214. [CrossRef] [PubMed]

6. Mclauchlan, K.; Higuera, P.E.; Miesel, J.; Rogers, B.M.; Schweitzer, J.; Shuman, J.K.; Tepley, A.J.; Varner, J.M.; Veblen, T.T.; Adalsteinsson, S.A.; et al. Fire as a fundamental ecological process: Research advances and frontiers. J. Ecol. 2020, 108, 2047-2069. [CrossRef]

7. Flannigan, M.; Stocks, B.; Turetsky, M.; Wotton, M. Impacts of climate change on fire activity and fire management in the circumboreal forest. Glob. Chang. Biol. 2009, 15, 549-560. [CrossRef]

8. Bond-Lamberty, B.; Wang, C.; Gower, S.T.; Bond-Lamberty, B. Net primary production and net ecosystem production of a boreal black spruce wildfire chronosequence. Glob. Chang. Biol. 2004, 10, 473-487. [CrossRef]

9. McRae, D.J.; Conard, S.G.; Ivanova, G.A.; Sukhinin, A.I.; Hao, W.M.; Koutzenogij, K.P.; Baker, S.P.; Ivanov, V.A.; Samsonov, Y.N.; Churkina, T.V.; et al. Fire regimes, variability in fire behavior, and fire effects on combustion and chemical and carbon emissions in Scotch Pine forests of central Siberia. Mitig. Adapt. Strat. Gl. 2006, 11, 45-74. [CrossRef]

10. Bowman, D.M.J.S.; Balch, J.K.; Artaxo, P.; Bond, W.J.; Carlson, J.M.; Cochrane, M.A.; D'Antonio, C.M.; DeFries, R.S.; Doyle, J.C.; Harrison, S.P.; et al. Fire in the Earth System. Science 2009, 324, 481-484. [CrossRef]

11. Johnstone, J.F.; Chapin, F.S.; Hollingsworth, T.N.; Mack, M.C.; Romanovsky, V.; Turetsky, M. Fire, climate change, and forest resilience in interior Alaska. Can. J. For. Res. 2010, 40, 1302-1312. [CrossRef]

12. Holden, Z.A.; Swanson, A.; Luce, C.H.; Jolly, W.M.; Maneta, M.; Oyler, J.W.; Warren, D.A.; Parsons, R.; Affleck, D. Decreasing fire season precipitation increased recent western US forest wildfire activity. Proc. Natl. Acad. Sci. USA 2018, 115, E8349-E8357. [CrossRef] [PubMed]

13. Perkins-Kirkpatrick, S.E.; Lewis, S.C. Increasing trends in regional heatwaves. Nat. Commun. 2020, 11, 3357. [CrossRef]

14. Turco, M.; Von Hardenberg, J.; AghaKouchak, A.; Llasat, M.C.; Provenzale, A.; Trigo, R.M. On the key role of droughts in the dynamics of summer fires in Mediterranean Europe. Sci. Rep. 2017, 7, 1. [CrossRef] [PubMed]

15. Ganteaume, A.; Camia, A.; Jappiot, M.; San-Miguel-Ayanz, J.; Long-Fournel, M.; Lampin, C. A Review of the Main Driving Factors of Forest Fire Ignition over Europe. Environ. Manag. 2012, 51, 651-662. [CrossRef] [PubMed]

16. Skinner, W.R.; Stocks, B.J.; Martell, D.L.; Bonsal, B.; Shabbar, A. The association between circulation anomalies in the mid-troposphere and area burned by wildfire in Canada. Theor. Appl. Climatol. 1999, 63, 89-105. [CrossRef]

17. Koutsias, N.; Xanthopoulos, G.; Founda, D.; Xystrakis, F.; Nioti, F.; Pleniou, M.; Mallinis, G.; Arianoutsou, M. On the relationships between forest fires and weather conditions in Greece from long-term national observations (1894-2010). Int. J. Wildland Fire 2013, 22, 493-507. [CrossRef]

18. Lagerquist, R.; Flannigan, M.; Wang, X.; Marshall, G.A. Automated prediction of extreme fire weather from synoptic patterns in northern Alberta, Canada. Can. J. For. Res. 2017, 47, 1175-1183. [CrossRef]

19. Jin, Y.; Randerson, J.T.; Goulden, M.L.; Goetz, S.J. Post-fire changes in net shortwave radiation along a latitudinal gradient in boreal North America. Geophys. Res. Lett. 2012, 39, 13403. [CrossRef]

20. French, N.H.F.; Whitley, M.A.; Jenkins, L.K. Fire disturbance effects on land surface albedo in Alaskan tundra. JGR Biogeosci. 2016, 121, 841-854. [CrossRef] 
21. Amiro, B.D.; Todd, J.B.; Wotton, B.M.; Logan, K.A.; Flannigan, M.D.; Stocks, B.J.; Mason, J.A.; Martell, D.L.; Hirsch, K.G. Direct carbon emissions from Canadian forest fires, 1959-1999. Can. J. For. Res. 2001, 31, 512-525. [CrossRef]

22. Vilén, T.; Fernandes, P.M. Forest Fires in Mediterranean Countries: CO2 Emissions and Mitigation Possibilities through Prescribed Burning. Environ. Manag. 2011, 48, 558-567. [CrossRef] [PubMed]

23. Liu, Y.; Goodrick, S.; Heilman, W.E. Wildland fire emissions, carbon, and climate: Wildfire-climate interactions. For. Ecol. Manag. 2014, 317, 80-96. [CrossRef]

24. Albrecht, B.A. Aerosols, Cloud Microphysics, and Fractional Cloudiness. Science 1989, 245, 1227-1230. [CrossRef] [PubMed]

25. Tummon, F.; Solmon, F.; Liousse, C.; Tadross, M. Simulation of the direct and semidirect aerosol effects on the southern Africa regional climate during the biomass burning season. J. Geophys. Res. Space Phys. 2010, 115, 19206. [CrossRef]

26. Bougiatioti, A.; Stavroulas, I.; Kostenidou, E.; Zarmpas, P.; Theodosi, C.; Kouvarakis, G.; Canonaco, F.; Prévôt, A.S.H.; Nenes, A.; Pandis, S.N.; et al. Processing of biomass-burning aerosol in the eastern Mediterranean during summertime. Atmos. Chem. Phys. Discuss. 2014, 14, 4793-4807. [CrossRef]

27. Wentworth, G.R.; Aklilu, Y.-A.; Landis, M.S.; Hsu, Y.-M. Impacts of a large boreal wildfire on ground level atmospheric concentrations of PAHs, VOCs and ozone. Atmos. Environ. 2018, 178, 19-30. [CrossRef]

28. Kalita, G.; Kunchala, R.K.; Fadnavis, S.; Kaskaoutis, D.G. Long term variability of carbonaceous aerosols over Southeast Asia via reanalysis: Association with changes in vegetation cover and biomass burning. Atmos. Res. 2020, 245, 105064. [CrossRef]

29. Li, F.; Lawrence, D.M.; Bond-Lamberty, B. Impact of fire on global land surface air temperature and energy budget for the 20th century due to changes within ecosystems. Environ. Res. Lett. 2017, 12, 044014. [CrossRef]

30. Li, F.; Lawrence, D.M. Role of Fire in the Global Land Water Budget during the Twentieth Century due to Changing Ecosystems. J. Clim. 2017, 30, 1893-1908. [CrossRef]

31. Robock, A. Surface cooling due to forest fire smoke. J. Geophys. Res. Space Phys. 1991, 96, $20869-20878$. [CrossRef]

32. Kitzberger, T.; Falk, D.A.; Westerling, A.L.; Swetnam, T.W. Direct and indirect climate controls predict heterogeneous early-mid 21st century wildfire burned area across western and boreal North America. PLoS ONE 2017, 12, e0188486. [CrossRef] [PubMed]

33. Lynch, A.H.; Beringer, J.; Kershaw, A.P.; Marshall, A.; Mooney, S.; Tapper, N.; Turney, C.S.; Van Der Kaars, S. Using the Paleorecord to Evaluate Climate and Fire Interactions in Australia. Annu. Rev. Earth Planet. Sci. 2007, 35, 215-239. [CrossRef]

34. De Sales, F.; Okin, G.S.; Xue, Y.; Dintwe, K. On the effects of wildfires on precipitation in Southern Africa. Clim. Dyn. 2018, 52, 951-967. [CrossRef]

35. Gorham, E. Northern Peatlands: Role in the Carbon Cycle and Probable Responses to Climatic Warming. Ecol. Appl. 1991, 1, 182-195. [CrossRef]

36. Apps, M.J.; Price, D.T.; Wisniewski, J. (Eds.) Boreal Forests and Global Change; Kluwer Academic Publishers: Dordrecht, The Netherlands, 1995; p. 564.

37. Vaganov, E.A.; Efremov, S.P.; Onuchin, A.A. Carbon balance and the emission of greenhouse gases in boreal forests and bogs of Siberia. In Advances in the Geological Storage of Carbon Dioxide; NATO Science Series IV; Lombardi, S., Altunina, L.K., Beaubien, S.E., Eds.; Springer: Dordrecht, The Netherlands, 2006; Volume 65, pp. 17-34.

38. Novenko, E.Y.; Tsyganov, A.N.; Pisarchuk, N.M.; Volkova, E.M.; Babeshko, K.V.; Kozlov, D.N.; Shilov, P.M.; Payne, R.J.; Mazei, Y.A.; Olchev, A.V. Forest history, peatland development and mid- to late Holocene environmental change in the southern taiga forest of central European Russia. Quat. Res. 2018, 89, 223-236. [CrossRef]

39. Hugelius, G.; Loisel, J.; Chadburn, S.; Jackson, R.B.; Jones, M.; Macdonald, G.; Marushchak, M.; Olefeldt, D.; Packalen, M.; Siewert, M.B.; et al. Large stocks of peatland carbon and nitrogen are vulnerable to permafrost thaw. Proc. Natl. Acad. Sci. USA 2020, 117, 20438-20446. [CrossRef]

40. Duncan, B.N.; Martin, R.V.; Staudt, A.C.; Yevich, R.; Logan, J.A. Interannual and seasonal variability of biomass burning emissions constrained by satellite observations. J. Geophys. Res. Space Phys. 2003, 108, 4100. [CrossRef] 
41. Wallenius, T. Major decline in fires in coniferous forests-Reconstructing the phenomenon and seeking for the cause. Silva Fenn. 2011, 45, 139-155. [CrossRef]

42. Santín, C.; Doerr, S.H. Fire effects on soils: The human dimension. Philos. Trans. R. Soc. B 2016, 371, 20150171. [CrossRef]

43. Hanes, C.C.; Wang, X.; Jain, P.; Parisien, M.-A.; Little, J.M.; Flannigan, M.D. Fire-regime changes in Canada over the last half century. Can. J. For. Res. 2019, 49, 256-269. [CrossRef]

44. Soja, A.J.; Shugart, H.H.; Sukhinin, A.I.; Conard, S.G.; Stackhouse, P.W., Jr. Satellite-Derived Mean Fire Return Intervals as Indicators of Change in Siberia (1995-2002). Mitig. Adapt. Strat. Gl. 2006, 11, 75-96. [CrossRef]

45. Vivchar, A. Wildfires in Russia in 2000-2008: Estimates of burnt areas using the satellite MODIS MCD45 data. Remote. Sens. Lett. 2011, 2, 81-90. [CrossRef]

46. Fiedler, C.E.; Friederici, P.; Petruncio, M. Monitoring Old Growth in Frequent-fire Landscapes. Ecol. Soc. 2007, 12, 22. [CrossRef]

47. Köppen, W. Das geographische System der Klimate. In Handbuch Klimatologie; In fünf Bänden (herausgegeben von W. Köppen und R. Geiger); Band, I., Teil, C., Eds.; Gebrüder Borntraeger: Berlin, Germany, 1936; p. 44. (In German).

48. Köppen, W. The thermal zones of the earth according to the duration of hot, moderate and cold periods and to the impact of heat on the organic world. Meteorol. Z. 2011, 20, 351-360. [CrossRef]

49. Peel, M.C.; Finlayson, B.L.; McMahon, T.A. Updated world map of the Köppen-Geiger climate classification. Hydrol. Earth Syst. Sci. 2007, 11, 1633-1644. [CrossRef]

50. Beck, H.E.; Zimmermann, N.E.; McVicar, T.R.; Vergopolan, N.; Berg, A.; Wood, E.F. Present and future Köppen-Geiger climate classification maps at 1-km resolution. Sci. Data 2018, 5, 180214. [CrossRef]

51. Vogel, B.; Vogel, H.; Bäumer, D.; Bangert, M.; Lundgren, K.; Rinke, R.; Stanelle, T. The comprehensive model system COSMO-ART-Radiative impact of aerosol on the state of the atmosphere on the regional scale. Atmos. Chem. Phys. Discuss. 2009, 9, 8661-8680. [CrossRef]

52. COSMO (Consortium for Small-Scale Modelling). Available online: http://cosmo-model.org/ (accessed on 28 July 2020).

53. Rivin, G.S.; Rozinkina, I.A.; Vil'Fand, R.M.; Alferov, D.Y.; Astakhova, E.D.; Blinov, D.V.; Bundel', A.Y.; Kazakova, E.V.; Kirsanov, A.A.; Nikitin, M.A.; et al. The COSMO-Ru system of nonhydrostatic mesoscale short-range weather forecasting of the Hydrometcenter of Russia: The second stage of implementation and development. Russ. Meteorol. Hydrol. 2015, 40, 400-410. [CrossRef]

54. Vil'Fand, R.M.; Kirsanov, A.A.; Revokatova, A.P.; Rivin, G.S.; Surkova, G.V. Forecasting the transport and transformation of atmospheric pollutants with the COSMO-ART model. Russ. Meteorol. Hydrol. 2017, 42, 292-298. [CrossRef]

55. Gorchakova, I.A.; Mokhov, I.I. The radiative and thermal effects of smoke aerosol over the region of Moscow during the summer fires of 2010. Izv. Atmos. Ocean. Phys. 2012, 48, 496-503. [CrossRef]

56. Konovalov, I.B.; Beekmann, M.; Kuznetsova, I.N.; Yurova, A.Y.; Zvyagintsev, A.M. Atmospheric impacts of the 2010 Russian wildfires: Integrating modelling and measurements of an extreme air pollution episode in the Moscow region. Atmos. Chem. Phys. Discuss. 2011, 11, 10031-10056. [CrossRef]

57. Mokhov, I.I.; Shukurova, L.M. Estimate for radiative forcing of smoke aerosol from 2010 summer fires based on measurements in the Moscow region. Izv. Atmos. Ocean. Phys. 2014, 50, 256-265.

58. LAADS. The Level-1 and Atmosphere Archive \& Distribution System. Available online: https://ladsweb. modaps.eosdis.nasa.gov (accessed on 28 July 2020).

59. Bondur, V.G. Satellite monitoring of trace gas and aerosol emissions during wildfires in Russia. Izv. Atmos. Ocean. Phys. 2016, 52, 1078-1091. [CrossRef]

60. Bondur, V.G.; Ginzburg, A.S. Emission of carbon-bearing gases and aerosols from natural fires on the territory of Russia based on space monitoring. Dokl. Earth Sci. 2016, 466, 148-152. [CrossRef]

61. Bondur, V.G.; Gordo, K.A. Satellite Monitoring of Burnt-out Areas and Emissions of Harmful Contaminants Due to Forest and Other Wildfires in Russia. Izv. Atmos. Ocean. Phys. 2018, 54, 955-965. [CrossRef]

62. Zängl, G.; Reinert, D.; Rípodas, P.; Baldauf, M. The ICON (ICOsahedral Non-hydrostatic) modelling framework of DWD and MPI-M: Description of the non-hydrostatic dynamical core. Q. J. R. Meteorol. Soc. 2014, 141, 563-579. [CrossRef] 
63. Lyons, E.A.; Jin, Y.; Randerson, J.T. Changes in surface albedo after fire in boreal forest ecosystems of interior Alaska assessed using MODIS satellite observations. J. Geophys. Res. Space Phys. 2008, 113, 02012. [CrossRef]

64. Wooster, M.J.; Roberts, G.; Perry, G.L.W.; Kaufman, Y.J. Retrieval of biomass combustion rates and totals from fire radiative power observations: FRP derivation and calibration relationships between biomass consumption and fire radiative energy release. J. Geophys. Res. Space Phys. 2005, 110, 24. [CrossRef]

65. Wiedinmyer, C.; Akagi, S.K.; Yokelson, R.J.; Emmons, L.K.; AlSaadi, J.A.; Orlando, J.J.; Soja, A.J. The Fire INventory from NCAR (FINN): A high resolution global model to estimate the emissions from open burning. Geosci. Model Dev. 2011, 4, 625-641. [CrossRef]

66. Kaiser, J.W.; Heil, A.; Andreae, M.O.; De Benedetti, A.; Chubarova, N.Y.; Jones, L.; Morcrette, J.-J.; Razinger, M.; Schultz, M.G.; Suttie, M.; et al. Biomass burning emissions estimated with a global fire assimilation system based on observed fire radiative power. Biogeosciences 2012, 9, 527-554. [CrossRef]

67. Doswell, C.; Schultz, D. On the use of indices and parameters in forecasting severe storms. Electron. J. Sev. Storms Meteorol. 2006, 1, 1-22.

68. Leuenberger, D.; Stoll, M.; Roches, A. Description of Some Convective Indices Implemented in the COSMO Model; Technical Report No. 17; Deutscher Wetterdienst: Offenbach am Main, Germany, 2010; pp. 1-18.

69. Amiro, B.; Orchansky, A.; Barr, A.; Black, T.; Chambers, S.; Iii, F.C.; Goulden, M.; Litvak, M.; Liu, H.; McCaughey, J.; et al. The effect of post-fire stand age on the boreal forest energy balance. Agric. For. Meteorol. 2006, 140, 41-50. [CrossRef]

70. Mölders, N.; Kramm, G. Influence of wildfire induced land-cover changes on clouds and precipitation in Interior Alaska-A case study. Atmos. Res. 2007, 84, 142-168. [CrossRef]

71. Casady, G.M.; Van Leeuwen, W.J.D.; Marsh, S.E. Evaluating Post-wildfire Vegetation Regeneration as a Response to Multiple Environmental Determinants. Environ. Model. Assess. 2009, 15, 295-307. [CrossRef]

72. Berner, L.T.; Beck, P.S.A.; Loranty, M.M.; Alexander, H.D.; Mack, M.C.; Goetz, S.J. Cajander larch (Larix cajanderi) biomass distribution, fire regime and post-fire recovery in northeastern Siberia. Biogeosciences 2012, 9, 3943-3959. [CrossRef]

73. Mamkin, V.; Kurbatova, J.A.; Avilov, V.; Mukhartova, Y.; Krupenko, A.; Ivanov, D.; Levashova, N.; Olchev, A.V. Changes in net ecosystem exchange of $\mathrm{CO}_{2}$, latent and sensible heat fluxes in a recently clear-cut spruce forest in western Russia: Results from an experimental and modeling analysis. Environ. Res. Lett. 2016, 11, 125012. [CrossRef]

74. Mamkin, V.; Kurbatova, J.; Avilov, V.; Ivanov, D.; Kuricheva, O.; Varlagin, A.; Yaseneva, I.; Olchev, A. Energy and $\mathrm{CO}_{2}$ exchange in an undisturbed spruce forest and clear-cut in the Southern Taiga. Agric. For. Meteorol. 2019, 265, 252-268. [CrossRef]

75. Kuz'mina, E.V.; Ol'chev, A.V.; Rozinkina, I.A.; Rivin, G.S.; Nikitin, M. Application of the COSMO-CLM mesoscale model to assess the effects of forest cover changes on regional weather conditions in the European part of Russia. Russ. Meteorol. Hydrol. 2017, 42, 574-581. [CrossRef]

76. Olchev, A.V.; Rozinkina, I.A.; Kuzmina, E.V.; Nikitin, M.A.; Rivin, G.S. Influence of forest cover changes on regional weather conditions: Estimations using the mesoscale model COSMO. IOP Conf. Series: Earth Environ. Sci. 2018, 107, 12105. [CrossRef]

77. Kislov, A.V.; Toropov, P.A.; Platonov, V.S.; Oltchev, A.V.; Varentsov, M.I. Regional climate modeling for geographical analysis. Vestn. Mosk. Univ., Ser. 5, Geogr. 2019, 5, 3-12. (In Russian).

78. Kaskaoutis, D.; Kharol, S.K.; Sifakis, N.; Nastos, P.; Sharma, A.R.; Badarinath, K.; Kambezidis, H. Satellite monitoring of the biomass-burning aerosols during the wildfires of August 2007 in Greece: Climate implications. Atmos. Environ. 2011, 45, 716-726. [CrossRef]

79. Vadrevu, K.P.; Lasko, K.; Giglio, L.; Justice, C. Vegetation fires, absorbing aerosols and smoke plume characteristics in diverse biomass burning regions of Asia. Environ. Res. Lett. 2015, 10, 105003. [CrossRef]

80. Gorbarenko, E.V.; Zhdanova, E.Y.; Chubarova, N.E.; Shilovtseva, O.A.; Nezval, E.I.; Soshinskaya, I.V. Radiation and light regime. In Climate of Moscow in Global Warning; MSU: Moscow, Russia, 2017; pp. 109-145. (In Russian).

81. Grell, G.A.; Freitas, S.R.; Stuefer, M.; Fast, J. Inclusion of biomass burning in WRF-Chem: Impact of wildfires on weather forecasts. Atmos. Chem. Phys. Discuss. 2011, 11, 5289-5303. [CrossRef]

82. Frankman, D.; Webb, B.W.; Butler, B.W.; Jimenez, D.; Forthofer, J.; Sopko, P.; Shannon, K.S.; Hiers, J.K.; Ottmar, R. Measurements of convective and radiative heating in wildland fires. Int. J. Wildland Fire 2013, 22, 157-167. [CrossRef] 
83. Potter, B.E.; Anaya, M.A. A Wildfire-relevant climatology of the convective environment of the United States. Int. J. Wildland Fire 2015, 24, 267-275. [CrossRef]

84. Zhang, Y.; Fan, J.; Logan, T.; Li, Z.; Homeyer, C.R. Wildfire Impact on Environmental Thermodynamics and Severe Convective Storms. Geophys. Res. Lett. 2019, 46, 10082-10093. [CrossRef]

85. Gibson, C.M.; Chasmer, L.E.; Thompson, D.K.; Quinton, W.L.; Flannigan, M.D.; Olefeldt, D. Wildfire as a major driver of recent permafrost thaw in boreal peatlands. Nat. Commun. 2018, 9, 1-9. [CrossRef]

86. Kirdyanov, A.V.; Saurer, M.; Siegwolf, R.; Knorre, A.A.; Prokushkin, A.S.; Sidorova, O.V.C.; Fonti, M.V.; Büntgen, U. Long-term ecological consequences of forest fires in the continuous permafrost zone of Siberia. Environ. Res. Lett. 2020, 15, 034061. [CrossRef]

87. Riley, K.L.; Loehman, R.A. Mid-21st-century climate changes increase predicted fire occurrence and fire season length, Northern Rocky Mountains, United States. Ecosphere 2016, 7, 01543. [CrossRef]

Publisher's Note: MDPI stays neutral with regard to jurisdictional claims in published maps and institutional affiliations.

(C) 2020 by the authors. Licensee MDPI, Basel, Switzerland. This article is an open access article distributed under the terms and conditions of the Creative Commons Attribution (CC BY) license (http://creativecommons.org/licenses/by/4.0/). 